\title{
'What is that to us? See to it yourself' (Mt 27:4): Making atonement and the Matthean portrait of the Jewish chief priests
}

\begin{abstract}
Author:
Dorothy Jean Weaver ${ }^{1,2}$

Affiliations:

${ }^{1}$ Department of New Testament Studies, Eastern

Mennonite Seminary, United

States of America

${ }^{2}$ Department of New

Testament Studies, Faculty of Theology, University of

Pretoria, South Africa

\section{Note:}

Prof. Dr Dorothy Jean

Weaver is a research fellow of Prof. Dr Andries G. van Aarde in the research project 'Biblical Theology and Hermeneutics' located in the Department of New Testament Studies, Faculty of Theology, University of Pretoria, Pretoria, South

Africa.
\end{abstract}

\section{Correspondence to:} Dorothy Jean Weaver

Email:

weaverdj@emu.edu

\section{Postal address:}

1200 Park Road, Harrisonburg, VA 22802

2462, United States of

America

Dates:

Received: 29 Apr. 2013

Accepted: 15 June 2014

Published: 29 Oct. 2014

How to cite this article: Weaver, D.J., 2014, "'What is that to us? See to it yourself" (Mt 27:4): Making atonement and the Matthean portrait of the Jewish chief priests', HTS Teologiese Studies/ Theological Studies 70(1), Art. \#2703, 8 pages. http:// dx.doi.org/10.4102/hts. v70i1.2703

\section{Read online:}

To read the Gospel of Matthew within its 1st century religious context is to read an intensely Jewish narrative. Central to the world of this Gospel are the Jerusalem temple, its administrators, the chief priests, and the sacrificial system which they are charged by Jewish law to officiate. This article assesses the Matthean portrait of the Jewish chief priests of Jesus' day against the scriptural backdrop which lays out their prominent role within Jewish religious life, namely 'making atonement' before God for the 'sins' of the people. In section one I sketch out the Matthean portrait of the scripturally assigned role of the priests, connecting this portrait to its biblical antecedents. In section two I assess the overall performance of the Matthean chief priests against the backdrop of their assigned role. In section three I address the question of atonement. Crucial here is 27:3-10, the account of Judas Iscariot, who returns his 30 silver coins to the chief priests and says (27:4a; emphasis mine), 'I have sinned, because I have handed over innocent blood'. Here I highlight Matthew's ironic modus operandi as he portrays the chief priests' non-priestly response to Judas. Additionally, I contrast Matthew's portrait of the Jewish chief priests with a brief portrait of Jesus' own ministry within the Jewish community, a ministry which fulfils the priestly role abandoned by the chief priests. I conclude my article in section four with brief reflections on the rhetorical impact of Matthew's portrait of the Jewish chief priests within his overall narrative.

\section{Introduction}

To read the Gospel of Matthew within its 1st century religious context is to read an intensely Jewish narrative. This narrative opens with a Jewish genealogy $(1: 1,2-16,17)$, beginning with Abraham, the 'father' of the Jewish people (1:1, 2, 17; cf. 3:9; DJW), and coming to its climax in the birth of Jesus the Jewish Messiah $(1: 1,16,17$; cf. 1:18). The narrative which follows, an account of the birth, childhood, ministry, death, and resurrection of Jesus Messiah, takes place against the backdrop of the Jewish religious world of 1 st century Palestine. ${ }^{2}$ This is a world prominently peopled with Jewish leaders (Pharisees ${ }^{3}$, Sadducees ${ }^{4}$, scribes $^{5}$, priests $/$ chief $_{\text {priests }}{ }^{6}$, and elders ${ }^{7}$ ), closely associated with Jewish meeting places (synagogue ${ }^{8}$, temple/house of God $^{9}$ ) and Jewish feasts (Passover/Unleavened Bread ${ }^{10}$, feast ${ }^{11}$ ), and regularly focused on Jewish scripture ${ }^{12}$, the commandments ${ }^{13}$, and what is lawful. ${ }^{14}$ This is likewise a world pervaded by the memory of the

1.All biblical citations reflect the New Revised Standard Version unless otherwise designated. All chapter or verse references are likewise Matthean unless otherwise designated.

2. That is, the pre-70 CE world of Jesus' day. Matthew's narrative depicts the world prior to the destruction of the Jerusalem temple by the Romans in 70 CE. Matthew's narrative itself is written most likely in the mid-80s CE, a vantage point from which it looks back at the destruction of the temple through the words of Jesus, who foretells this event $(22: 7 ; 23: 38 ; 24: 1-2)$.

3.Thus Pharisaioi:3:7; 5:20; 9:11, 14, 34; 12:2, 14, 24, 38; 15:1, 12; 16:1, 6, 11, 12; 19:3; 21:45; 22:15, 34, 41; 23:2, 13, 14, 15, 23, 25, 26, 27,$29 ; 27: 62$.

4.Thus Saddoukaioi: 3:7; 16:1, 6, 11, 12; 22:23, 34

5.Thus grammateis: $2: 4 ; 6: 20 ; 7: 29 ; 8: 19 ; 9: 3 ; 12: 38 ; 15: 1 ; 16: 21 ; 17: 10 ; 20: 18 ; 21: 15 ; 23: 2,13,14,15,23,25,27,29,34 ; 26: 3,57 ; 27: 41$ cf. 13:52.

6.Thus hiereis: 8:4; 12:4, 5; archiereis: 2:4; 16:21; 20:18; 21:15, 23, 45; 26:3, 14, 47, 51, 57, 58, 59, 62, 63, 65; 27:1, 3, 6, 12, 20, 41, 62; 28:11.

7.Thus presbyteroi: 15:2; 16:21; 21:23; 26:3, 47, 57, 59; 27:1, 3, 12, 20, 41; $28: 12$.

8.Thus synagoge: $4: 23 ; 6: 2,5 ; 9: 35 ; 10: 17 ; 12: 9 ; 13: 54 ; 23: 6,34$

9.Thus hieron: 4:5; 12:5, 6; 21:12, 14, 15, 23; 24:1; 26:55; vaos: 23:16, 17, 21, 35; 26:61; 27:5, 40, 51; oikos/oikos tou theou: 12:4; 21:13.Cf. 23:38, where Jesus associates the temple about to be destroyed as 'your house' (= the 'house' of 'Jerusalem, the city that kills the prophets and stones those who are sent to it!').

10.Thus pascha: 26:2, 17, 18, 19; azymos: 26:17.

11.Thus heorte: $26: 5 ; 27: 15$

12.Thus nomos (law): 5:18; 12:5; 22:36; 23:23; vomos kai prophetai (law and prophets): 5:17; 7:12; 22:40; cf. 11:13.

13.Thus entole/entolai: 5:19; 15:3, 6; 19:17; 22:36, 38, 40.

14.Thus exestin: $12: 2,4,10,12 ; 14: 4 ; 19: 3 ; 20: 15 ; 22: 17 ; 27: 6$.

Note: Prof. Dr Dorothy Jean Weaver is a research associate of Prof. Dr Andries G. van Aarde, Department of New Testament Studies, Faculty of Theology, University of Pretoria, South Africa.

Copyright: @ 2014. The Authors. Licensee: AOSIS OpenJournals. This work is licensed under the Creative Commons | Attribution License. 
Jewish prophets of ancient days ${ }^{15}$ and a history shaped by their prophetic pronouncements. ${ }^{16}$ The conflict which drives the plot of Matthew's narrative is a quintessentially Jewish conflict, the ongoing and ultimately deadly confrontation between Jesus Messiah and the Jewish leadership, who repeatedly contest his messianic status and 'authority'17 and who persistently seek to 'destroy' him, ${ }^{18}$ 'kill' him, ${ }^{19}$ or 'put him to death' ${ }^{20}$ Matthew's narrative retains its Jewish character and context up to its conclusion (28:20) and on into the world of Matthew's first readers with a reference by the narrator to a story which 'is still told among the Jews to this day' $^{\prime}(28: 15 b)$.

Central to the 1st century Palestinian world of Jewish religious life depicted within Matthew's narrative are the Jerusalem temple, its primary administrators, the chief priests, and the sacrificial system which they are charged by Jewish law to officiate, ${ }^{21}$ a system in which gifts are 'offered' on the altar (5:23-24; 8:1-4; cf. 12:3-5), blood is 'poured out' to make atonement (26:28), ${ }^{22}$ and the 'sins' of the people are 'forgiven' (26:28b). The task of this article is to assess the Matthean portrait of the Jewish chief priests of Jesus' day ${ }^{23}$ against the scriptural (largely Levitical) backdrop which lays out their primary role within Jewish religious life, namely 'making atonement' before God for the 'sins' of the people. ${ }^{24}$ In section one I will sketch out the Matthean portrait of the scripturally assigned role of the priestly class within Jewish religious life, connecting this portrait to its biblical antecedents. In section two I will then assess the overall performance of the

15.Thus $5: 12 ; 12: 39 ; 13: 17 ; 16: 4,14 ; 23: 29,30,31,37$. See also the references to John the Baptist $(11: 9,13 ; 14: 5 ; 21: 26)$, Jesus $(13: 57 ; 21: 11,46 ; 23: 37)$, and Jesus disciples $(10: 41 ; 23: 34)$ as 'prophets'.

16.Thus the 'fulfilment citations' of Matthew's Gospel: 1:22: 2:5, 15, 17, 23; 3:3; 4:14 8:17; 12:17; 13: 35; 21:4; 24:15; 26:56; 27:9, 35.

17.Thus exousia: 7:29; 9:2-8; 21:23-27; cf. 9:10-13; 12:1-8, 9-14; 15:1-9.

18.Thus apollymi: 12:14; 27:20.

19.Thus apokteino: $16: 21 ; 17: 23 ; 21: 38,39 ; 26: 4 ;$ cf. $23: 37$.

20.Thus thanatoo: 26:59; $27: 1$; cf. 20:18; 26:66.

21.The primary scriptural locus of the Jewish laws governing the sacrificial system is Leviticus. For summary discussions of the sacrificial system depicted within Leviticus, see Hayes (1998), Ber (2010), Anderson and Culbertson (1986), Judisch (1984), and Weaver (1994).

22.Note the clarifying comments of Hayes (1998:6), who links atonement to the pollution of the sanctuary: 'Basic to [rituals of atonement] in Leviticus is the view that human impurity and wrongdoing pollute the sanctuary. This concept is not made explicit in Leviticus, but is alluded to sufficiently to establish its importance.' Hayes (1998:6) then points to Leviticus 15:31 (cf. Lv 20:3; Nm 19:13, 20) as evidence of this underlying concept: 'You shall set apart the Israelites from their impurity f this underlying concept: You shall set apart the Israelites from their impurity lest they die in their impurity by their polluting [rendering impure] my Tabernacle which is in their midst.' Accordingly, the sacrifices offered in the sanctuary serve to cleanse the sanctuary itself of its pollution, a pollution brought about by human wrongdoing.

23.From a narrative critical standpoint, the portrait of the Matthean chief priests has frequently been collapsed into the larger character group of 'Jewish leaders,' a category which includes Pharisees, Sadducees, scribes, Herodians, and elders/ elders of the people. As Kingsbury (1987:5) notes: 'Because the rhetorical effect of the way in which these several groups are presented is such as to make of them a monolithic front opposed to Jesus, they can, narrative-critically, be treated as a single character.' From his assessment of the evidence at hand, Kingsbury (1987:60) then concludes: 'The notion that "evilness" is the root trait, or fundamental quality, characterizing the Jewish leaders is in full accord with the tenor of Matthew's story.' This observation, however, true as it may be within Matthew's narrative allows Kingsbury and those who follow his lead to overlook the narrative critical nows Kingsury and those who follow his lead to ov the narrative critical $\grave{a}$-vis the people of Israel. This article seeks to redress that oversight.

24.See, for example, Leviticus 16:34, describing the annual Day of Atonement: 'This shall be an everlasting statute for you, to make atonement for the people of Israel once in the year for all their sins' (emphasis mine). See also Leviticus 4:20, 26, 31, 35; 5:6, 10, 13, 16, 18; 6:7; 16:16, 30, 34; 19:22; Numbers 15:25, 28.
Matthean chief priests against the backdrop of their assigned role, highlighting their prominent characteristics as Matthew portrays them (cf. Weaver 2009). In section three I will address the question of atonement. A crucial text here will be $27: 3-10$, the account of Judas Iscariot, who returns his 30 silver coins to the chief priests and announces to them (27:4a; emphasis mine), 'I have sinned, because I have handed over innocent blood'. Here I will highlight Matthew's ironic modus operandi as he portrays the chief priests' non-priestly response to an Israelite who comes to them confessing his $\sin .{ }^{25} \mathrm{I}$ will then contrast Matthew's portrait of the Jewish chief priests with a brief portrait of Jesus' own priestly ministry within the Jewish community, a ministry which fulfils the priestly role effectively abandoned by the chief priests, ${ }^{26}$ namely mediating atonement vis-à-vis the 'sins' of God's people (1:21; $26: 27-28)$. I will conclude my article in section four with brief reflections on the rhetorical impact of Matthew's portrait of the Jewish chief priests within his overall narrative.

\section{'Go, show yourself to the priest' (8:4b)}

\section{The assigned role of the Jewish priestly class within Matthew's narrative}

Whilst Matthew nowhere sets forth a detailed description of the scripturally assigned role of the priestly class within the Jewish community of 1st century Palestine, a close reading of Matthew's narrative yields significant bits and pieces of such a description. Fundamental to the task of the chief priests is their scriptural calling to maintain the Jerusalem temple, that is, the 'house of God' (12:4), 'my [ = God's] house' (21:13// Is 56:7), or the place where God 'dwells' (23:21), as a 'house of prayer' for the people of Israel (21:13//Is 56:7). It is the worship of God which lies at the root of the priestly calling and it is this priestly calling to give oversight to the worship life of the Jewish community which Jesus proclaims to the chief priests as he enters the temple during his Passover visit to Jerusalem and physically overturns the commercial enterprise which he finds there (21:12-13). Here Jesus draws on the words of the Prophet Isaiah to remind the chief priests of their sacred charge vis-à-vis the wider Jewish community: 'It is written, "My house shall be called a house of prayer"' (21:13a/ / Is 56:7). ${ }^{27}$

The modus operandi of Jewish priests for carrying out their priestly calling to the worship life of the Jewish community is, in turn, sacrificial in character. The Jewish 'house of

25.Cf. 27:24, where Pilate, the Roman governor, responds with the same words ('See to it yourselves') to the Jewish crowds clamouring, at the instigation of the chie priests and the elders, for the crucifixion of Jesus (27:20-23).

26.Cf. 2:6b, where Matthew cites Micah 5:2 in identifying Jesus as one who wil 'shepherd my [= God's] people Israel,' even as these same people are later depicted by Jesus himself $(9: 36 ; 15: 24)$ as 'the lost sheep of the house of Israel,' people thus apparently 'unshepherded' by their designated religious leaders.

27.Whilst Jesus' words initially appear to address the 'money changers' and 'those who [sell] doves,' those whose commercial enterprise he overturns (2:13 cf. 2:12), who [sell] doves, those whose commercial enterprise he overturns (2:13 cf. 2:12),
it is in fact the chief priests and the scribes who not only 'see' and 'hear' what is going on (21:15) but likewise respond verbally to Jesus (21:16a). From Matthew's going on (21:15) but likewise respond verbally to Jesus (21:16a). From Matthew's
perspective, accordingly, it is these chief priests and scribes whom Jesus ultimately addresses with his words. 
prayer' is in fact a house of sacrifice, where gifts are 'offered' on the altar (5:23-24; 8:1-4; cf. 12:3-5), blood is 'poured out' to make atonement (cf. 26:28a), and the 'sins' of the people are 'forgiven' (cf. 26:28b). It is the priests who administer this sacrificial system, officiate at these sacrifices, and serve in this way as human agents of divine forgiveness. The everyday tasks of Jewish priests, as reflected within Matthew's narrative, point, detail by detail, to the requirements laid out in the Torah for the Jewish sacrificial system.

Day by day the priests sacrifice the 'gifts' (doron) brought by worshippers to the 'altar' (thysiasterion) in the temple (5:23-24; 23:18-20; cf. 8:1-4). Following an elaborate ritual outlined in Leviticus 14:1-32, they examine those whose leprosy has made them ritually unclean, validate their cleansing, and sacrifice the required offering brought by those who have been cleansed: '[G]o, show yourself to the priest and offer the gift [doron] that Moses commanded ...' (8:4). ${ }^{28}$ They also deposit financial gifts in the temple treasury (eis ton korbanan: 27:6; cf. 15:5 doron//Mk 7:11 korban, ho estin doron).

Sabbath by Sabbath they '[eat] the bread of the Presence' (tous artous tes protheseos: 12:4; cf. Lv 24:5-9; Ex 40:23; 2 Macc 10:3), twelve loaves baked from 'choice flour' (Lv 24:5), 'set ... in order before the LORD regularly as a commitment of the people of Israel' (Lv 24:8), and designated specifically 'for Aaron and his descendants, who shall eat them in a holy place' (Lv 24:9). Sabbath by Sabbath they likewise carry out their regular priestly duties in spite of Sabbath work prohibitions (12:5; cf. Nm 28:9-10).

Day by day and year by year the Jewish priests 'make atonement' (exilaskomai) on behalf of the people, ${ }^{29}$ so that their 'sins' (hai hamartiai) might be 'forgiven' (aphiemi)..$^{30}$ This happens both individually, on a case by case basis, ${ }^{31}$ and collectively, in an elaborate, annual ritual on the Day of Atonement. ${ }^{32}$ This annual ritual is enacted by the high priest inside 'the curtain of the temple (katapetasma tou naou: Mt 27:51: cf. Lv 16:2, 12, 15), that curtain which sets apart 'the most holy place' (Ex 26:31-34), that is, the place

28.Whilst Jesus and the leper are in Galilee, close to Capernaum (cf. 8:5) and far from the Jerusalem temple, Jesus' command is nevertheless conceivable within within Matthew's literary context. Keener (2009:263) notes that '[ $p$ ] riests lived throughout Palestine and came to Jerusalem only during their course ...; som Jewish traditions thus expect a leper to submit to local priests' inspection ... before
offering the sacrifice in the temple (Lv 14:2-3)'.

29.See footnote 24

30.Thus Leviticus $4: 20,26,31,35 ; 5: 6,10,13,16,18 ; 6: 7 ; 16: 16,30,34 ; 19: 22$ Numbers $15: 25,28$. Whilst Matthew's narrative makes no mention of 'atonement' (hilaskomai/exilaskomai), there is strategic reference to 'forgiveness of sins' (aphesis + hai hamartiai) within a covenantal and sacrificial context: 'This is my [= Jesus'] blood of the covenant which has been poured out for many for the forgiveness of sins' (26:28; cf. 1:21).

31.Thus the Levitical case laws governing the sacrifices to be brought and the atonement to be made for a wide range of sins and/or trespasses: Leviticus 4:13$21 ; 22-26,27-31,32-35 ; 5: 1-6,7-10,11-13,14-16,17-19 ; 6: 1-7,24-30 ; 7: 7-10$. See by contrast Matthew 27:4, where such a ritual of atonement should clearly take place but does not.

32.Thus Leviticus 16:2-34. Cf. Matthew 26:28, which alludes to just such an annual atonement ritual. in which God 'dwells' (cf. Mt 23:21). ${ }^{33}$ This ritual, clearly the single most important of all Jewish rituals, is enjoined on the priests in due solemnity by the word of the Lord to Moses (Lv 16:34): 'This shall be an everlasting statute for you, to make atonement for the people of Israel once in the year for all their sins.'

Finally, in addition to their sacrificial work in 'making atonement' for the people, the priests likewise play a crucial deliberative role in ensuring that the Jewish community is 'absolved of bloodguilt' (Dt 21:8; cf. Mt 27:6 with its reference to 'blood money') in those cases where 'innocent blood' has been shed by an unknown perpetrator (Dt 21:1-9; cf. Mt 27:4). In the midst of an elaborate ritual of absolution carried out by the elders of the town nearest the dead body (Dt 21:1-4, 6-8), the priests are called into action as a deliberative group (Dt 21:5; emphasis mine):

Then the priests, the sons of Levi, shall come forward, for the LORD your God has chosen them to minister to him and to pronounce blessings in the name of the LORD, and by their decisions all cases of dispute and assault shall be settled.

The urgency of their deliberative work in this ritual of absolution is apparent in the motive clause which concludes this piece of case law (Dt 21:9; emphasis mine): 'So you shall purge the guilt of innocent blood from your midst, because you must do what is right [LXX: good and pleasing (kalos kai arestos)] in the sight of the LORD.' The deliberative role of the Jewish priests in 'purg[ing] the guilt of innocent blood' from the Jewish community is, accordingly, crucial to the broad covenantal commitment of the Jewish people spelt out in Deuteronomy 6:1-25, a commitment summarised in the call of Deuteronomy 6:18: 'Do what is right and good [LXX: pleasing and good, to areston kai to kalon] in the sight of the LORD.'

\section{'And they conspired' (26:4a) The narrative portrayal of the Matthean chief priests vis-à-vis their priestly calling}

As Matthew portrays it, the scripturally assigned vocation of the Jewish chief priests is both liturgical and deliberative in its focus. Their calling, broadly framed, is to maintain the Jerusalem temple ('my [= God's] house'), as the 'house of prayer' (21:13//Is 56:7) for the Jewish people. Within that broad calling their primary tasks are to administer the sacrificial system carried out at the 'altar' (5:23-24; 23:18-20, 35), to make atonement on behalf of those who have 'sinned' (26:28; cf. 1:21), and to take deliberative action to remove the guilt of 'innocent blood' from the midst of the community (cf. 27:4,6).

33.There is sturdy scholarly discussion concerning which of two temple curtains, the 'outer' curtain (cf. Ex 26:36) or the 'inner' curtain (cf. Ex 26:31-33), is in focus within Matthew 27:51 (thus Carter 2000:536; Keener 2009:686-687; Luz 2005:565-566; Witherington 2006:521). There is broad consensus, however, that Matthew's concept certainly includes the 'inner' curtain, that which separates the 'holy place' from the 'most holy place' (Ex 26:33), even if it might not exclude the 'outer' curtain. As Luz puts it (2005:565) "[t]he narrator speaks of "the curtain" 'It does not appear to bother him that there is more than one.' But see Carter's minority viewpoint (2000:536) which excludes the 'inner' curtain from Matthew's minority viewpoin
consideration. 
But the chief priests who appear 'on stage' within Matthew's narrative do not for the most part visibly carry out the activities which Matthew has outlined for them. Whilst the narrative clearly implies that the chief priests are regularly engaged in a full range of liturgical tasks, ${ }^{34}$ it does not for the most part portray them in the act of carrying out these tasks. Matthew offers his readers no real-time images of the chief priests serving at the altar in the temple,,$^{35}$ offering the gifts brought by the worshippers, or mediating the forgiveness of God to those who have sinned. Nor do Matthew's readers witness the chief priests eating the bread of the presence or otherwise fulfilling their Sabbath duties. Where Matthew does portray the chief priests engaged in liturgical tasks, he does so only in ironic fashion. ${ }^{36}$ Accordingly, Matthew's narrative portrayal of the chief priests within their realworld context bears little overt resemblance to the Matthean portrait of their scriptural calling.

The chief priests, as Matthew portrays them, belong to the highest echelon of Jewish society in 1st century Palestine; and they have, accordingly, the greatest religious and political power within the Jewish community. One of their prime assets is their wealth in physical resources of all kinds. The Matthean chief priests appear to have significant money at their collective disposal (cf. 26:15b; 27:3; 28:12), evidently associated with the commercial enterprise which they have established at the Jerusalem temple, an enterprise based on the essential and thus legitimate sale of sacrificial animals (21:12: 'those who sold doves/tas peristeras'; cf. Lv 5:7; 12:8), the accompanying and necessary exchange of money for the requisite temple currency (21:12: 'the moneychangers'/ton kollybiston; cf. Ex 30:13), ${ }^{37}$ and the collection of the temple tax (to didrachma: 17:24-27).

In addition to their disposable wealth, the chief priests likewise oversee the maintenance of a massive and magnificent piece of real estate, the Jerusalem temple. This facility is unimaginably 'great' in popular conception (megas/ mega; cf. 12:6; 23:17), a complex of 'buildings' (tas oikodomas tou hierou: 24:1) that calls for special notice by travellers to Jerusalem. The temple is constructed 'stone upon stone'

34.Thus, for example, the references to 'altar' (thysiasterion: 5:23, 24; 23:18, 19, 20), 'gift' (doron: 5:23, 24; 8:4; 15:5; 23:18, 19), and 'Passover' (pascha: 26:2, 17, 18 , $19)$, a celebration for which the priests must slaughter the lambs brought to the temple by the celebrants (cf. Jn 1:29, 36; 19:31). See also the reference in 21:12-13 to the market operated on the temple grounds for exchanging money into temple currency (cf. Ex 30:13) and for buying and selling sacrificial animals, in this case doves (cf. Lv $5: 7 ; 12: 8$ ).

35.But see Jesus' reference (23:35) to 'Zechariah, son of Barachiah,' a figure from Jewish history who was apparently on duty in the temple when he was 'murdered between the sanctuary and the altar'. For a discussion of the historical (2005:154155) difficulties surrounding the interpretation of this Matthean reference, see Luz.

36. One such liturgical task which the chief priests perform 'on stage' within Matthew's narrative, albeit in clearly ironic fashion, is to deal with the disposal of money brought to the temple $(27: 3-5)$, ostensibly for deposit in the temple treasury (27:6). Elsewhere Matthew portrays the chief priests frequently involved in the deliberative task of 'taking counsel' (symbouleuo; symboulion lambano: 26:4 $27: 1,7 ; 28: 12$ ). But these deliberations, in similar fashion, provide a bitterly ironic counterpart to the chief priests' calling to ensure that 'innocent blood' be removed from the Jewish community.

37.As Long (1997:236) notes: 'The popular notion that the temple had become commercialized and Jesus was "cleansing" it, restoring it to its previous sacred purpose, is false. The sacred role of the temple was the offering of sacrifices and the making of offerings under the direction of the priests. If these functions were to be fulfilled, then someone had to provide the animals to be sacrificed, and someone had to change the Greek and Roman coins the pilgrims brought with them into Jewish coins suitable for offerings.' Instead, as Long concludes (1997:236), Jesus' tewish coins suitable for offerings.' Instead, as Long concludes (1997:236), Jesus'
temple action is not 'reform' of the temple cultus but rather 'revolution': '[Jesus] is not improving the temple; he is attacking the temple, and it is doomed ...' (lithos epi lithon: 24:2) with huge Herodian ashlars, adorned with 'gold' (chrysos: 23:16-17), and topped with an impressive landmark, 'the pinnacle of the temple' (to pterygion tou hierou: 4:5), dangerously high above the ground far below (cf. 4:5-6). Central to this temple and crucial to the worship which takes place there are its 'altar' of acacia wood (thysiasterion: 5:23, 24; 23:18, 19, 20, 35; cf. Ex 27:1-8) and a beautifully woven cloth, 'the curtain of the temple' (to katapetasma tou naou: 27:51; cf. Ex 26:31), which sets apart 'the most holy place' (Ex 26:31-34), namely the place in which God 'dwells' (cf. Mt 23:21). This entire complex, then, serves as 'the house' (ho oikos: 23:38) of the Jewish chief priests, their primary locus of engagement, and, by the same token, the quintessential gathering place of the entire Jewish people in the heart of their 'holy city' (ten hagian polin: 27:53). ${ }^{38}$ This is the temple and this is the altar by which Jewish people 'swear' when they make their solemn oaths to God (23:16-22). This is the temple whose 'destruction' is virtually unthinkable (cf. 26:61; 27:40) and whose predicted demise thus portends 'desolation' for the entire Jewish people (cf. 23:38).

If the chief priests have significant disposable wealth and a massive and strategic piece of Jerusalem real estate, they likewise have significant human resources. When they need to make arrests on behalf of the temple, they do so with the assistance of a temple guard, a 'large crowd with swords and clubs from the chief priests and the elders of the people' (26:47; cf. 26:55; emphasis mine), ${ }^{39}$ a guard which includes the personal slave of the high priest himself (ton doulon tou archiereos: 26:51). For his part the high priest Caiaphas (26:3, 57) has his own 'palace' (aule: 26:3, 58, 69), a residence large enough to house the gatherings of the entire Jewish 'council' or Sanhedrin (synedrion: 26:59; cf. 26:3, 57; 27:1) and staffed both by personal 'slaves' (cf. ton doulon tou archiereos: 26:51) and by 'guards' who oversee the court proceedings of the council (ton hypereton: 26:58; cf. 5:25).

Along with their wealth in physical and human resources, the Matthean chief priests likewise have significant social, religious, and political capital, both within the Jewish community and beyond. They associate regularly and strategically with other highly placed groups from the Jewish community: Pharisees $(21: 45 ; 27: 62)$, scribes/scribes of the people $(2: 4 ; 16: 21 ; 20: 18 ; 21: 15 ; 26: 57 ; 27: 41)$, and elders/elders of the people $(16: 21 ; 21: 23 ; 26: 3,47,57 ; 27: 1$, $312,20,41) .{ }^{40}$ They and their religious associates constitute, collectively, the literati of the Jewish community, those who

38.As Matthew depicts it, the Jerusalem temple is the gathering place for the entire Jewish community, from the greatest to the least: chief priests $(21: 15,23,45)$ scribes (21:15), elders of the people (21:23), Pharisees (21:45; 22:15, 34, 41) Sadducees $(22: 23,34)$, Herodians $(22: 16)$, those who are buying and selling sacrificial animals (21:12), moneychangers (21:12), those who are sitting and teaching(26:55), Jewish visitors to Jerusalem (24:1), the blind and the lame (21:14) and children (21:15).

39.Cf. the comments of Keener (2009:640), who cites Luke 22:4, 52 amongst other sources and concludes: 'The guards Judas led to Jesus probably belonged to the Levite temple guard ... and the armed auxiliary police who worked for them.'

40.Note also Matthew's references to the Sadducees $(3: 7 ; 16: 1,6,11,12 ; 22: 23,34)$, a historically prominent Jewish group in 1st century Palestine prior to the Jewish Revolt of 66-70 CE. The Sadducees are likewise (but for Matthew, only apparently) a constituent group of the Jewish Sanhedrin. Whilst Matthew does not associate the Sadducees directly with the chief priests, Carter (2000:96; emphasis mine) the Sadducees directly with the chief priests, Carter (2000:96; emphasis mine)
notes that 'Josephus attests the membership of both Pharisees and Sadducees among the wealthy ... and politically powerful ..., including the chief priests'. 
'read' the Jewish scriptures ${ }^{41}$ and parse out their meaning for the everyday lives of the Jewish people. ${ }^{42}$ The chief priests collaborate prominently with their religious associates on the Sanhedrin or 'council' (26:59; cf. 26:3, 57; 27:1), a powerful Jewish deliberative body which meets in the high priest's palace (26:3; cf. 26:57), is moderated by the high priest (26:57, $62,63,65)$, and issues verdicts extending all the way to death sentences (26:65-66).

The social, religious, and political power of the Matthean chief priests within the Jewish community likewise positions them strategically as the prominent and crucial liaison with Rome, the ultimate political power of their day and their world. The chief priests of Matthew's narrative maintain regular and strategic collaboration with the Roman forces who occupy 1st century Palestine. From the moment of Jesus' birth (2:16) to the moment of his death and even beyond (27:62-66; 28:11-15) the Matthean chief priests enjoy easy access to the local representatives of empire and mutually beneficial relationships with the Roman overlords of Palestine and/or their client rulers: Herod, the Jewish client king (2:3-6), 'the Gentiles' (20:18), and Pilate, the Roman governor (27:1-2, 6266 ; 28:11-15; cf. 27:12-13). When they have need for human resources beyond their own, the chief priests have ready access to a Roman 'guard' (koustodia: 27:65; 28:11) comprised of Roman 'soldiers' (stratiotai: 28:12).

As Matthew portrays them, the Jewish chief priests are indisputably people of wealth and power. But from Matthew's perspective, theirs is wealth and power gone corrupt on all fronts. In fact the chief priests of Matthew's narrative direct all of their wealth and power to one central and overriding goal, namely, the destruction of their political rival, Jesus, whose 'authority' they question (21:23-27), whose claim to 'messiahship' they label 'blasphemy' (26:6365; cf. 21:15-16), and for whose messianic 'inheritance' they ultimately kill him (21:38-39). Matthew's portrayal of the real-world performance of the Jewish chief priests vis-à-vis their scriptural calling is bleak and bitterly ironic throughout.

The Matthean chief priests are politically and religiously strategic in their words and actions, as they seek first to counter and then to destroy their rival. In response to a politically weighted question that Jesus puts to them concerning John the Baptist (21:24-25a), they choose their words with exquisite care and obvious expedience in order to avoid Jesus' censure on the one hand and the wrath of the Jewish people on the other (21:25-27a): 'If we say ... But if we say ... So they answered Jesus, "We do not know."'). They choose their actions with equal care and expedience, as they plot to arrest Jesus and kill him. Theirs will be a 'stealth' operation (dolo: 26:4) and 'not during the festival, or there

41. Matthew strategically associates each of these elite Jewish groups with the ability to 'read': Pharisees $(12: 3,5 ; 19: 4)$, scribes (21:16; cf. 2:5-6), elders (21:42), and chief 'read': Pharisees (12:3,5; 19:4), scribes (21:16; cf. 2:5-6), elders (21:42),
priests $(21: 16,42 ;$ cf. $2: 5-6)$, as well as Sadducees (22:31; see footnote 40 ).

42.Thus, for example, questions concerning Sabbath observance $(12: 2 ; 10)$, divorce $(19: 3)$, payment of taxes $(22: 17)$, levirate marriage $(22: 23-27)$, the greatest commandment $(22: 34-36)$, oaths $(23: 16,18)$, and tithing (23:23-24). may be a riot [thorybos] among the people' (26:5). ${ }^{43}$ When they are faced with tainted 'blood money' resulting from their police action against Jesus (time haimatos: 27:6; cf. 27:3-4a), they weigh their options and take the religiously expedient decision (27:6-7).

If the Matthean chief priests are strategic in their words and actions, they are likewise conspiratorial in their efforts against Jesus. Within Matthew's rhetoric the confluence of references to 'gathering together' (synago: 2:4; 26:3, 57; 27:17, 62; 28:12) and 'taking counsel' (symbouleuo: 26:4; symboulion lambano: 27:1, 7; 28:12) serve collectively to depict the Matthean chief priests as persistent conspirators. ${ }^{44}$ They are introduced to the world of conspiracy when Herod the king 'call[s] together [synago: 2:4] all the chief priests and scribes of the people' and inveigles them into his own paranoid scheme against 'the child who has been born king of the Jews' (2:2; cf. 2:3-8). Years later they themselves 'gather' (synago: 26:3) and 'conspire' (symbouleuo: 26:4) against Jesus. They then 'gather' (synago: 27:57) in the house of Caiaphas the high priest to conduct a kangaroo court, seeking from the outset to condemn Jesus on the 'false testimony' (pseudomartyrian: 26:59) of 'false witnesses' (pseudomartyron: 26:60). They 'confer together' (symboulion lambano: 27:1) against Jesus before turning him over to Pilate. They 'gather' (synago: 27:62) before Pilate to demand measures to secure the tomb of Jesus and prevent a resurrection fraud by Jesus' disciples. In their final appearance within Matthew's narrative (28:11-15) they 'assemble' (synago: 28:12) with the elders and 'devise a plan' (symboulion lambano: 28:12), their own resurrection fraud, to account for the empty tomb.

The Matthean chief priests are as corrupt in their dealings as they are conspiratorial in their actions. Thus, even as they carry out what are in principle legitimate priestly tasks, they fail to act with integrity. Whilst they have legitimate funds to use for the purposes of temple worship (cf. 17:24-27; 21:12$13^{45}$ ), they use this wealth instead as capital for bribes paid to hit men (26:14-16), real-estate transactions that have the character of money-laundering (27:7-10), and hush-money paid to co-conspirators for passing on a false story (28:11-15). For his part Jesus accuses them of transforming the house of God (21:13a) into a 'den of robbers' (21:13b//Jr 8:11a), to which they retreat for security after carrying out lives of injustice. ${ }^{46}$

When they engage their deliberative responsibilities as a council $(26: 3-5 ; 27: 57-59)$, a task which should focus on

43.Cf. 21:45, where the chief priests do not take action to arrest Jesus as a result of their fear of the crowds.

44.Cf. 12:14 and 22:15, where the Pharisees also engage in conspiracy (symboulion lambano) against Jesus.

45. See footnote 38 .

46. Cf. Jeremiah 7:8-11a: 'Here you are, trusting in deceptive words to no avail. Will you steal, murder, commit adultery, swear falsely, make offerings to Baal, and go after other gods that you have not known, and then come and stand before me in this house, which is called by my name, and say, "We are safe!" only to go on doing this house, which is called by my name, and say, "We are safe!" only to go on doing
all these abominations? Has this house, which is called by my name, become a den of robbers in your sight?' 
removing the guilt of 'innocent blood' from the midst of the Jewish community (haima anaition: Dt 21:8; cf. 21:5), they first conspire to kill their rival (26:4) and then intentionally corrupt their own judicial processes by engaging the services of 'false witnesses' (pseudomartyron: 26:60) to provide 'false testimony' (pseudomartyrian: 26:59). When they ultimately pronounce the death sentence on the defendant in their trial (26:65-66), they ironically make themselves guilty of blood which they will shortly and implicitly acknowledge to be 'innocent' (athoon: 27:4; cf. 27:6). Thus, rather than fulfilling their covenantal commitment (Dt 21:9//6:18) to 'do what is right in the sight of the LORD,' they instead incur the very blood guilt that they are charged to remove from the Jewish community (cf. Dt 21:5, 8).

Whilst the chief priests have access to the highest levels of Roman power in Palestine, access which could be used for the purposes of 'righteousness' (dikaiosyne: 3:15; cf. 14:3-4), ${ }^{47}$ they use this access instead for nefarious and self-serving purposes. When Herod the Jewish client king needs strategic information to assist him in destroying a political rival, the chief priests and scribes provide him with the intelligence he seeks (2:1-6). When the chief priests wish to destroy their own political rival (cf. 21:38), they hand him over to 'the Gentiles' (20:18), namely, to 'Pilate the Roman governor' (cf. 27:2). When the chief priests later fear resurrection fraud, they seek and gain an immediate audience with Pilate to express their concerns and to appeal for a remedy (27:62-66). When the chief priests and elders face the terrifying conundrum of an empty tomb, they plot their own resurrection fraud and promise to 'secure' the Roman governor, if the truth ever reaches his ears (28:11-15). ${ }^{48}$

If the Matthean chief priests are conspiratorial in their actions and corrupt in their dealings, they are likewise cruel and abusive on levels both physical and emotional. In predicting his upcoming passion, Jesus warns his disciples (16:21) that he will 'undergo great suffering [polla pathein] at the hands of the elders and chief priests and scribes' and (20:19) that these same people will ultimately 'hand him over [paradidomi] to the Gentiles to be mocked [empaizo], flogged [mastigoo] and crucified [stauroo]'. ${ }^{49}$ Jesus' words are borne out vividly by the events that transpire in Jerusalem. After the high priest and the Jewish Sanhedrin have condemned Jesus to death (26:65-66), they themselves attack Jesus physically (26:67), 'spitting' in his face [emptyo], 'striking' him (kolaphizo), and 'slapping' him (rhapizo). Their physical abuse is matched, in turn, by their verbal abuse. As they spit and strike and slap, they taunt Jesus verbally (26:68): 'Prophesy to us, you Messiah! Who is it that struck you?' Then, just as Jesus has

47.John the Baptist, for example, who has been called by Jesus to join him in the task of 'fulfilling all righteousness' (3:15), uses his access to Herod the tetrarch in order to speak truth to power (14:3-4), an act which costs him his life (14:5-12).

48. Matthew does not clarify whether this action to 'secure' the Roman governor will be one of friendly persuasion, bribe, or deceit. But regardless of their intended methods, the goal of the chief priests is self-serving and nefarious.

49. Here the chief priests are depicted as not only inflicting their own suffering on Jesus but also handing him over to others precisely so that these others can inflict even greater suffering on him. predicted, they 'hand him over' (paradidomi: 27:2; cf. 26:2) to the Romans, to be 'flogged' (phragelloo: 27:26), 'mocked' (empaizo: 27:29, 31) and 'crucified' (stauroo: 26:2; 27:22, 23, 26, 31,$35 ;$ cf. 27:38). As Jesus hangs dying on a Roman cross, the chief priests, scribes, and elders 'mock' him (empaizo: 27:41) still further with a vicious onslaught of charges (27:42-43): 'He saved others; he cannot save himself. He is the King of Israel; let him come down from the cross now, and we will believe in him. He trusts in God; let God deliver him now, if he wants to; for he said, "I am God's Son"'. ${ }^{50}$ Such is the portrait of cruelty and abuse by the Matthean chief priests.

\section{'What is that to us? See to it yourself' (27:4b)}

\section{The Matthean chief priests and atonement for God's people}

Matthew's portrait is vivid; and his message is unmistakable. The consistent modus operandi of the Jewish chief priests reflects conspiracy, corruption, and callous cruelty. Their ongoing activities, as Matthew portrays them, stand in sharp and ironic contrast to their priestly vocation. In fact, Matthew never depicts the Jewish chief priests carrying out their central scriptural calling and their covenantal commitment to 'make atonement' before God for the 'sins' of the people (cf. Lv 16:34). Remarkably absent from Matthew's Jewish narrative, a narrative in which matters of ' $\sin ^{\prime 51}$ and 'forgiveness' (aphesis) ${ }^{52}$ figure significantly (1:21; 26:28), are any real-time images of the Jewish chief priests dealing in person with the 'sins' of the Jewish people. Despite their massive and amazing 'temple' complex (cf. 4:5; 12:6; 24:1-2), with its 'altar' for sacrifice $(5: 23,24 ; 23: 18,19,20,35)$ and its 'curtain' that closes off the place where God 'dwells' (27:51; cf. 23:21), the chief priests are never visibly engaged in the act of 'making atonement'.

Instead, when they are called to this very act, the central and primary task of their priestly vocation, in a moment of crucial importance, the chief priests completely and callously abandon their priestly calling (27:4b) vis-à-vis an Israelite who confesses his ' $\sin ^{\prime}$ to them in an act of suicidal desperation (27:3-4a, 5). Judas Iscariot has recently conspired with these same chief priests (26:14-16) and accepted a bribe of 30 silver coins in exchange for 'handing [Jesus] over' to them (paradidomi: 26:15, 16; translation mine). ${ }^{53}$ But when he learns of Jesus' 'condemnation' and realises the deadly implications of his own actions (27:3a), Judas now 'repents' (metamelomai:

50.The biting irony of Matthew's narrative, however, is that the chief priests, scribes, and elders both acknowledge and proclaim the deep truth about Jesus' identity, even as they mock him and ridicule his claim to be 'God's Son'.

51.Thus hamartia: 1:21; 3:6; 9:2, 5, 6; 12:31; 26:18; hamartano: 18:15, 21.

52.Thus aphesis 26:28; aphiemi: 6:12, 14, 15; 9:2, 5, 6; 12:31, 32; 18:21, 27, 32, 35.

53.Judas's act of 'handing Jesus over' (paradidomi: 10:4; 17:22; 20:18; 26:2, 15, 16 , $21,23,24,25,45,46,48 ; 27: 3,4$ ) is fundamentally no different in kind than that of the chief priests, scribes, and elders of the people who 'hand [Jesus] over' (paradidomi: cf. 20:19; 27:2, 18) to 'the Gentiles' (20:19), namely to 'Pilate the governor' $(27: 2,18)$. Nor does Judas's act differ essentially from that of Pilate himself, who 'hands [Jesus] over' (paradidomi: 27:26) to his crucifixion. 
27:3b) of his participation in this conspiracy against Jesus. ${ }^{54}$ In urgent distress he comes to the chief priests in the posture of a penitent seeking atonement, ${ }^{55}$ bearing both the 30 silver coins (27:3c) and a damning self-confession (27:4a): 'I have sinned by betraying innocent blood.' Judas clearly knows the Jewish scriptures and he is clearly aware that a 'curse' hangs over him for his actions (Dt 27:25): 'Cursed be anyone who takes a bribe to shed innocent blood.' The issue that Judas brings to the chief priests is, therefore, not merely a matter of ' $\sin$ ' to be atoned, but even more crucially, a matter of life and death (cf. Dt 19:11-13).

The chief priests know the scriptures well (cf. 2:4-6). Likewise, they know what is at stake for Judas. But rather than carrying out their covenantal commitment and initiating a life-giving process to 'make atonement' on behalf of Judas's $\sin ^{56}$ the chief priests cynically abdicate all priestly responsibility as they throw Judas's sin back into his face with the words, 'What is that to us? See to it yourself' (27:4b). The irony of Matthew's narrative rhetoric here is profound on not one but two levels. To begin with, the Jewish chief priests, who are bitter rivals of Jesus Messiah $(1: 1,16,17,18)$ and who have conspired constantly and strategically to kill him and gain his messianic 'inheritance' (21:38), have themselves instead, in one unguarded moment, given away any possible claim to their own religious and political leadership of the Jewish people. By abdicating their most fundamental task, namely 'making atonement' on behalf of the 'sins' of the Jewish people, ${ }^{57}$ the Matthean chief priests have proven by their own words that they have no claim to be called the 'shepherds' of Israel (9:36; cf. 2:6) and no claim on the 'inheritance' of the Jewish 'vineyard' (cf. 21:33-46). In the words of David Garland (1993:255), '[Judas] is turned away by the callous shepherds who have no regard for the sheep'.

But if the Matthean chief priests have abdicated their own calling and thereby given up any claim to the leadership of the Jewish people, theirs is an act of ironic necessity. As they acknowledge openly in conferring on the use of the 30 silver coins (27:6b), there is a clear reason why they cannot make atonement on behalf of Judas's sins. Given that they themselves are the prime movers in the conspiracy against Jesus, the bribe they have paid to Judas is indeed 'blood money' (27:6b, Garland 1993:255). Accordingly, they share

54.Whilst the language of 'repentance' (metamelomai: 27:3b) diverges here from that found in the proclamations of John the Baptist and Jesus (metanoeo: 3:2; 4:17 $11: 20,21 ; 12: 41)$, this language nevertheless connotes a serious and life-changing response. As Matthew tells the story, Jesus himself uses this same term to rebuke the chief priests and the elders of the people, because they have not 'repented' (metamelomai: 21:32; cf. 21:29; DJW) at the preaching of John the Baptist (cf. 3:2, (metamelomai: 21:32; cf. 21:29; DJW) at the preaching of John the Baptist (cf. 3:2, is metanoeo). But see Hare (1993:314) for the view that Judas's act of 'repenting' (metamelomai) is not the 'genuine repentance' reflected in the verb metanoeo.

55.Cf. Hare (1993:314), who does not credit the genuine character of Judas's 'repentance' but notes nevertheless that Judas 'lamely "atones" for his sin by returning the tainted money'.

56.As Witherington (2006:505) notes: '[The chief priests] could have suggested various recourses or even sacrifices for $\sin . .$.

57.Cf. the comments of Carlson (2010:478): 'Though given the role of absolving Israel of bloodguilt (Deut 21:1-9, 19:8-13), the religious leaders are no longer able to fulfill such a role because of their own bloodguilt (21:33-45, 23:29-36).' both Judas's sin (27:4a) and Judas's 'curse' (cf. Dt 27:25). ${ }^{58}$ They are in fact even more in need of atonement than Judas, seeing as they have not 'repented' of their actions (21:28; cf. 27:20, 41-43; 28:11-15). Ultimately, in the words of Garland (1993):

Judas ... [has made] a fatal mistake by returning to the temple to seek absolution through his co-conspirators when the temple is no longer the place of God's presence or the seat of forgiveness (p. 255)

Nor will ultimate outcomes be positive for the Matthean chief priests and their scripturally assigned role as 'Atoners in Chief' of the Jewish people. When Jesus dies, the 'curtain of the temple' will be 'torn in two, from top to bottom' (27: 51a) in a massive and symbolic display of divine power which will open the place where God 'dwells' to the public view of Jews and Gentiles alike and will, by the same token, fundamentally reshape the geography of atonement. Ultimately Jerusalem, the 'holy city' (4:5) of the Jewish people will itself be 'burned' (22:7) and the entire temple complex, the central locus of the chief priests' current activities, will be 'destroyed' so totally that 'not one stone will be left ... upon another,' but 'all will be thrown down' (24:2; cf. 26:61; 27:40). In an act of profound and unintended irony the chief priests, even before the death of Jesus, have already pronounced the judgement of God on themselves and their leadership role within the Jewish community. In response to a story told by Jesus about conspiratorial and vicious vineyard tenants who kill the son of the vineyard owner and do not return the fruits of the vineyard, the chief priests (21:41) give voice to their own demise: 'He [i.e. God, the divine vineyard owner] will put those wretches to a miserable death, and lease the vineyard to other tenants who will give him the produce at the harvest time.' Within Matthew's narrative rhetoric there is thus no salvific future for the Jerusalem temple with its elaborate sacrificial system for 'making atonement'. Nor is there a salvific future for the Jewish chief priests, who serve as the officiants of this sacrificial system.

Instead, Matthew's narrative rhetoric pointedly replaces the priestly role of the Jewish chief priests with the priestly role of Jesus himself. ${ }^{59}$ Jesus is the one whose name and whose life vocation, given to him before birth by divine agency, spell out the act of atonement for the 'sins' of 'his people' (1:21; emphasis mine): '... [A]nd you are to name him Jesus, for he will save his people from their sins.' Jesus is the one who throughout his earthly ministry pronounces God's 'forgiveness' to humans (aphiemi: 9:2, 5) with divinely-given 'authority on earth to forgive sins' (aphienai hamartias: 9:6). Jesus is the one who 'saves' those who reach out or call out to him (sozo: 8:25; 9:21, 22; 14:30). Jesus is the one who 'shepherds [God's] people Israel' (ton laon mou ton Israel: 2:6; cf. 9:36; 25:32; 26:31), is a 'great light' to 'the people who sit in darkness' (o laos o kathemenos en skotei: 4:16//Is 9:2), and ministers in their midst (en to lao: 4:23; cf. 9:35). Jesus is the one who is 'greater than the temple' (tou hierou meizon: 12:6) and

58.Cf. Witherington's comment (2006:505): 'But since [the chief priests] admit [the existence of "blood money"], they also admit they are guilty of bribing someone to betray a Jew unto death. In other words, they are as guilty of Deuteronomy 27:25 betray a Jew unto death. In other words, they are as guilty of
in one sense as Judas is.' In a similar vein see Hare (1993:313).

59.For a study of Jesus as source of atonement within Matthew's Gospel, see Gibbs (2008:211-225). 
whose ministry persistently reflects God's 'desire' for "mercy and not sacrifice' (eleos ... kai ou thysian: 9:13; 12:7; Hs 6:6). In his ultimate act of faithfulness to the will of $\operatorname{God}(26: 39,42$; cf. 26:44), Jesus himself becomes the sacrificial blood offering which transforms God's covenant with God's people for all time to come (26:28; cf. 20:28): '[T] his is my blood of the covenant [to haima mou tes diathekes] which is poured out for many for the forgiveness of sins [eis aphesin hamartion].' The salvific and durative impact of Jesus' blood offering becomes visible for all to see at the very moment of his death, when God reaches down from heaven and 'tears' the curtain of the temple 'in two, from top to bottom' (27:51a), thus destroying, definitively and beyond reversal, both the hidden locus of the Jewish chief priests' activity in making atonement and, by the same token, the entire sacrificial system over which they officiate in order to make such atonement.

Thus, in the penultimate irony of Matthew's narrative rhetoric, aside from the Resurrection, God's last laugh (cf. Ps 2:4-6), it is the Jewish chief priests themselves, those who seek to gain the Jewish messianic 'inheritance' through killing Jesus (cf. 21:38), who achieve instead the devastation of their temple curtain (27:51), the destruction of their temple (24:1-2), and ultimately, by the same token, the loss of their own priestly function as temple officiators. Accordingly, it is the Jewish chief priests themselves who, in Matthew's unrelenting narrative irony, forfeit their own role as 'Atoners in Chief' for the Jewish people. Instead atonement is enacted for all time (cf. 28:20b) through the death of Jesus, who fills the role that the Jewish chief priests have abdicated and 'saves his people from their sins' (1:21) through his 'blood of the covenant which is poured out for many for the forgiveness of $\operatorname{sins}^{\prime}(26: 28)$.

\section{'See, your house Is left to you, desolate' (23:38) \\ Matthew's narrative rhetoric and the ironies of God}

Within the late 1st century real world behind Matthew's narrative, a mere 15 years or so following the epoch-changing destruction of the Jewish temple in Jerusalem by the forces of the Roman empire, the narrative rhetoric of Matthew's Gospel is unrelenting in its condemnation of the Jewish chief priests of Jesus' day. In a real world where Jerusalem lies 'burned' (22:7), its people 'destroyed' (22:7), its leadership 'put ... to a miserable death' (21:41), and 'not one stone' of the temple is 'left ... upon another' (24:2), Matthew's narrative rhetoric sees the unmistakable judgement of God in the downfall of Jerusalem, the destruction of the temple, and the dissolution of the sacrificial system officiated by the Jewish chief priests. In Matthew's view this divine judgement is charged above all to the account of the chief priests themselves, as a result of their cynical abdication of their scripturally assigned role, not only in making atonement for the sins of their people (cf. 27:4), but also in ensuring that the guilt of 'innocent blood' is removed from their midst (cf. 27:6). In this post-70 CE world of massive devastation and disorientation, where the wider Jewish community of Palestine and the emerging Jewish messianic community reflected by Matthew and his church are struggling to rediscover their respective self-identities beyond the Jerusalem temple and the Jewish holy city, Matthew's narrative rhetoric speaks a bold and unmistakable word.

For the wider Jewish community Matthew's word is a mirror which reflects their present catastrophic reality (23:38): 'See, your house is left to you desolate.' The geography of atonement has shifted tectonically and for all time. The Jerusalem temple is no longer and will never again be the locus of atonement for the people of God. But in this very word of desolation lie the seeds of the ultimate 'good news' of Matthew's Gospel. God will not be thwarted. God's passion for the atonement of human sin will never be abated. In the stunning and salvific irony of Matthew's narrative rhetoric it is precisely those who abdicate their own role in the atonement of God's people who are the unwitting agents through whom God initiates that tectonic shift in the geography of atonement. Those who recognise the guilt of 'blood money' in their hands (27:6) have no way of knowing in that moment that the very blood which occasions their guilt will shortly be 'poured out for many,' people such as them included, 'for the remission of sins' including such as theirs (26:28). Atonement is God's last word. Such is the irony of Matthew's narrative rhetoric and such is the ultimate 'good news' of Matthew's Jewish Gospel. Let the reader understand.

\section{Acknowledgements Competing interests}

The author declares that she has no financial or personal relationship(s) that may have inappropriately influenced her in writing this article.

\section{References}

Anderson, M. \& Culbertson, P., 1986, 'The inadequacy of the Christian doctrine of atonement in light of Levitical sin offering,' Anglican Theological Review 68(4), 303-328.

Ber, V., 2010, 'The social dimension of atonement in the Torah,' Ex Auditu 26, 110-124.

Carlson, R.P., 2010, 'From villain to tragic figure: The characterization of Judas in Matthew,' Currents in Theology and Mission 37(6).

Carter, W., 2000, Matthew and the margins: A sociopolitical and religious reading, Orbis, Maryknoll.

Garland, D.E., 1993, Reading Matthew: A literary and theological commentary on the first Gospel, Crossroad, New York.

Gibbs, J.A., 2008, 'The Son of God and the Father's wrath: Atonement and salvation in Matthew's Gospel,' Concord Theological Quarterly 72(3), 211-225.

Hare, D.R.A., 1993, Matthew: Interpretation, John Knox, Louisville.

Hayes, J.H., 1998, 'Atonement in the Book of Leviticus,' Interpretation: A Journal of Bible and Theology 52(1), 5-15.

Judisch, D.McC.L., 1984, 'Propitiation in the language and typology of the Old Testament,' Concordia Theological Quarterly 48(2/3), 221-243.

Keener, C.S., 2009, The Gospel of Matthew: A socio-Rhetorical commentary, Eerdmans, Grand Rapids.

Kingsbury, J.D., 1987, 'The developing conflict between Jesus and the Jewish leaders in Matthew's Gospel: A literary-critical study,' Catholic Biblical Quarterly 49(1), 58. Long, T.G., 1997, Matthew, Westminster, Louisville. (Westminster Bible Companion). Luz, U., 2005, Matthew 21-28: A Commentary, Fortress, Minneapolis.

Weaver, D.J., 1994, 'On imitating God and outwitting Satan: Biblical perspectives on forgiveness and the community of faith,' The Mennonite Quarterly Review 68(2), 151-169.

Weaver, D.J., 2009, “'They did to him whatever they pleased": The exercise of political power within Matthew's narrative,' HTS Teologiese Studies/Theological Studies 65(1), 2009, Art. \#319, 13 pages. http://dx.doi.org10.4102/hts.v65i1.319

Witherington, B., 2006, Matthew, Smyth \& Helwys, Macon. (Smyth \& Helwys Bible Commentary). 